\title{
STOCKHOLM \\ NATURAL RADIOCARBON MEASUREMENTS III
}

\author{
H. GÖTE ÖSTLUND and LARS (,. ENCSTRAND
}

Radioactive Dating Laboratory, Ceological Survey of Sweden, Stockholm 50

\section{INTRODUCTION}

This paper is a direct continuation of the second date list released from this laboratory (östlund, 1959), and the technique of preparation and the characteristics of our two 3-atmospheres (arbon dioxide counters are substantially unchanged (Östlund 1957a, b). As in previous lists, our standard is oak wood, grown A.D. 1845-1855 in Stockholm. corrected for radioactive decay to 1960. As usual, the counting rates have been corrected according to the massspectrometrically measured $\mathrm{C}^{13} / \mathrm{C}^{12}$ ratio in each sample of purified carbon dioxide. In this scale the U. S. National Bureau of Standards Natural Radiocarbon Standard (NBS standard) gives a counting rate which is $104.5 \pm$ $0.4 \%$ of our age-corrected oak standard. Taking into account that our oak has a $\mathrm{C}^{13} / \mathrm{C}^{12}$ ratio of 25 per mil lower than the Chicago PDB- $\mathrm{C}^{13}$ standard, our age figures can, by subtracting 55 years, he converted to the new, international radiocarbon age scale proposed by Broecker and Olson (1959).

In each error are included the statistical uncertainties of the measurements of the sample and related standard and background figures, together with the small error in the half-life of radiocarbon, the latter assumed to be $5568 \pm 30$ years. The variation of the $\mathrm{C}^{14}$ activity of the biosphere during past times, as reported by de Vries (1958), has not been taken into account.

\section{ACKNOWLEDGMENTS}

As previously, the major part of the routine work has been performed excellently by Miss Vivan Jacobson; Mr. Ryhage and his staff at Karolinska Institutet, Stockholm, have made the $\mathrm{C}^{13}$ determinations, which we highly appreciate.

\section{SAMPLE DESCRIPTIONS}

I. GEOLOGIC SAMPLES-SWEDEN

\section{A. Interglacial and Interstadial Samples}

\section{St-492. Porsi}

Sample of ooze below $9 \mathrm{~m}$ till at Porsi, Jokkmokk, Lappland $\left(66^{\circ} 28^{\prime} \mathrm{N}\right.$ Lat, $20^{\circ} 43^{\prime} \mathrm{E}$ Long), Sweden. Coll. by I. Hector, Porsi; subm. by C. Lundqvist, Geological Survey of Sweden (to he published). Comment (C.L.): the ooze is interglacial, which was expected.

\section{Ingebäck series}

Samples of marine clay, low in organic matter, and very low in carbonate, cut from a core taken at Ingebäck in the valley of the river Cöta Älv, $11 \mathrm{~km}$ $\mathrm{N}$ of Göteborg $\left(57^{\circ} 48^{\prime} \mathrm{N}\right.$ Lat, $12^{\circ} 00^{\prime} \mathrm{E}$ Long), Sweden. Core revealed an unexpectedly thick layer of sediments, namely, $90 \mathrm{~m}$ to the rock. Coll. and 
subm. hy F. Brotzen, Ceological Survey of Sweden. Samples of about $0.5 \mathrm{~kg}$ were burned without pretreatment.

\section{St-450. Ingebäck 4}

$10,710 \pm 150$

Beccari zone, postglacial. Depth 4.0 to $4.3 \mathrm{~m}$.

\section{St-449. Ingebäck 12}

Beccari zone, postglacial. Depth 12.5 to $12.8 \mathrm{~m}$.

\section{St-431. Ingebäck 14}

$16,040 \pm 200$

Lowest Beccari level, postglacial. Depth 14.8 to $15.1 \mathrm{~m}$.

St-447. Ingebäck 33

$15,740 \pm 290$

Lowest part of the upper Late-Glacial. Depth 33.1 to $34.1 \mathrm{~m}$.

St-430. Ingebäck $\mathbf{5 5}$

$15,200 \pm 250$ $56.1 \mathrm{~m}$.

Lowest part of conglomerate of the lower Late-Glacial. Depth 55.6 to

\section{St-448. Ingebäck 59}

Upper part of interstadial sandy clay. Depth 59.1 to $60.0 \mathrm{~m}$.

\section{St-429. Ingebäck 64}

$\mathbf{2 9 , 0 0 0}+\mathbf{1 3 0 0}$ $65.0 \mathrm{~m}$.

Lowest part of interstadial sandy clay, resting on gravel. Depth 64.0 to Comment (F.B., G.ö.) : work with this series is being continued, but it is already clear that the two lowest samples indicate a late interstadial.

\section{St-439. Hällby}

\section{B. Postglacial Strandlines and Peat Bogs}

Wood found at $6 \mathrm{~m}$ depth, covered by sand and clay Strömsholmsåsen, $800 \mathrm{~m}$ SW of Hällby, $5 \mathrm{~km} \mathrm{~W}$ of Eskilstuna, Sö esker land ( $59^{\circ} 23^{\prime} \mathrm{N}$ Lat, $16^{\circ} 25^{\prime} \mathrm{E}$ Long), Sweden. Measured in the program of the study of the process of crustal uplift. Subm. and described by G. Lundqvist (1959b), Geological Survey of Sweden.

\section{St-462. Kärna mosse}

$7720+120$

Wood in peat under the Ancylus limit, $1 \mathrm{~km}$ ESE of the church of Kärna, W of Linköping, Östergötland ( $58^{\circ} 05^{\prime} \mathrm{N}$ Lat, $16^{\circ} 03^{\prime} \mathrm{E}$ Long), Sweden. Coll. 1909 by the late H. Munthe; subm. by G. Lundqvist, Geological Survey of Sweden, from the museum of the Survey. Comment (G.L.): according to earlier knowledge this locality was supposed to date the Ancylus limit, but the obtained $\mathrm{C}^{14}$ age shows this shoreline to be younger than that.

\section{Lidamossen series}

Samples of peat from cores taken from the raised bog Lidamossen, $10 \mathrm{~km}$ ESE of Eskilstuna, Södermanland ( $59^{\circ} 20^{\prime} \mathrm{N}$ Lat, $17^{\circ} 42^{\prime} \mathrm{E}$ Long), Sweden. These measurements were made in order to study the development of the bog, especially its recurrence surface (R.S.), and the isolation level (indicating the time of its isolation from the sea). Coll. by C. Larsson; subm. and described by G. Lundqvist (1959b), Geological Survey of Sweden. Core no. 4 was in a 
central part of the bog, and cores no. 2 and 7 were more peripherally located. The stratigraphically identical R.S. was dated by samples above and below the R.S. in each of the three cores.

\section{St-463. Lida 9}

Core 4. Above the R.S., $120 \mathrm{~cm}$ below the surface.

St-464. Lida 10

Core 4. Below the R.S., 130 to $135 \mathrm{~cm}$ below the surface.

St-467. Lida 13

Core 7. Above the R.S., 70 to $80 \mathrm{~cm}$ below the surface.

St-469. Lida 14

Core 7. Below the R.S., 80 to $85 \mathrm{~cm}$ below the surface.

St-470. Lida 15

Core 2. Above the R.S., 40 to $50 \mathrm{~cm}$ below the surface.

St-471. Lida 16

Core 2. Below the R.S., 60 to $70 \mathrm{~cm}$ below the surface.

$$
\mathbf{7 0 0} \pm \mathbf{8 5}
$$

St-465. Lida 11

Core 4. $175 \mathrm{~cm}$ below the surface.

St-466. Lida 12

$1020 \pm 90$

$540 \pm 85$

$850 \pm 85$

$245 \pm 80$

$670 \pm 105$

Core 4. The isolation level, 440 to $450 \mathrm{~cm}$ below the surface.

Comment (G.L.) : from the first six of these listed samples it is seen that the R.S. in this bog is not synchronous over the entire bog but becomes younger toward the periphery; this was unexpected. In addition, the whole R.S. is younger than had previously supposed.

\section{Stormossen series}

Samples of peat collected in profiles of the bog Stormossen, $10 \mathrm{~km} \mathrm{SW} \mathrm{of}$ Eskilstuna, Södermanland $\left(59^{\circ} 20^{\prime} \mathrm{N}\right.$ Lat, $16^{\circ} 20^{\prime} \mathrm{E}$ Long $)$, Sweden. This investigation was made in order to study both the development of a bog and the process of crustal uplift. Thus, special interest is given to the ages of the recurrence surface and the isolation level. Coll., subm., and described by G. Lundqvist (1959b), Geological Survey of Sweden.

St-494. Stormossen 1

$1580 \pm 90$

Core $3.240 \mathrm{~cm}$ below the surface. Indicates the age of the quagmire.

\section{St-495. Stormossen 2}

$240 \pm 80$

Core $5.20 \mathrm{~cm}$ below the surface.

St-496. Stormossen 3

Core 8. The level of isolation, $4.00 \mathrm{~cm}$ below the surface.

St-497. Stormossen 4

Core $8.265 \mathrm{~cm}$ below the surface. First occurrence of Picea pollen curve.
St-498. Stormossen 5
$2570 \pm 100$

Core $8.200 \mathrm{~cm}$ below the surface. Beginning of continuous Picea pollen curve.

St-499. Stormossen 6

$2070 \pm 90$

Core 8. An earlier recurrence surface (R.S.), $150 \mathrm{~cm}$ below the surface. 
Core 8. Below the well-developed R.S., $100 \mathrm{~cm}$ below the surface. This R.S. corresponds stratigraphically to the level of St- 495 .
St-501. Stormossen 8
$1180 \pm 130$

Immediately above the well-developed R.S., $85 \mathrm{~cm}$ below the surface.

\section{St-441. Peskehaure}

\section{Various Geologic Samples}

Subfossil stump of pine, found above the present tree limit $\mathrm{S}$ of lake Peskehaure, Lappland ( $66^{\circ} 55^{\prime} \mathrm{N}$ Lat, $16^{\circ} 33^{\prime} \mathrm{E}$ Long), Sweden. Coll. by the late Fr. Svenonius; subm. by G. Lundqvist, Geological Survey of Sweden from its museum.

\section{Gulf of Bothnia series}

Three samples of clay containing a small amount of organic matter, taken as an integral part of an investigation of the geochronology of northern Sweden as reflected in the bottom sediments of the Gulf of Bothnia. The samples were ooze-varved clay situated directly above the underlying gray clay, the latter considered to be glacial. Expected age was 6500 to 7000 B.c. Coll. and subm. by A. Jerbo, Geological Survey of Sweden.

\section{St-432. Bothnia A}

$6050 \pm 110$

$\left(61^{\circ} 22^{\prime} \mathrm{N}\right.$ Lat, $17^{\circ} 27^{\prime} \mathrm{E}$ Long.) Water depth $82 \mathrm{~m}$ (echo-sounding). Depth in postglacial sediment $10.5 \mathrm{~m}$.

\section{St-433. Bothnia B}

$5980 \pm 140$

$\left(63^{\circ} 07^{\prime} \mathrm{N}\right.$ Lat, $19^{\circ} 27.5^{\prime} \mathrm{E}$ Long.) Water depth $169 \mathrm{~m}$ (echo-sounding). Postglacial sediment depth $7.5 \mathrm{~m}$.

St-434. Bothnia C

$\left(65^{\circ} 23^{\prime} \mathrm{N}\right.$ Lat, $22^{\circ} 55^{\prime}$ E Long.) Water depth $92 \mathrm{~m}$ (echo-sounding). Postglacial sediment depth $8 \mathrm{~m}$.

\section{ARCHAEOLOGIC SAMPIES - SWEDEN \\ A. Lappland and Neighboring Provinces}

\section{St-403. Borgasjön}

$470 \pm 80$

Sample of birch trunks used in the construction of a dwelling place at Lake Borgasjön, Dorotea parish, Lappland ( $64^{\circ} 51^{\prime} \mathrm{N}$ Lat, $14^{\circ} 58.5^{\prime} \mathrm{E}$ Long), Sweden. In a hearth under the ruptured roof were found a scraper and several other pieces of quartz. Coll. 1950 and subm. by H. Hvarfner, Royal Office of Antiquities, Stockholm. Comment (H.H. and G.ö.) : charcoal from the hearth was also dated. One large piece, St-402A, gave a date of $3450 \pm 250 \mathrm{yr}$. From the remaining material (smaller pieces of charred wood and other plant remnants), a new portion was measured. This preparation, St-402B,' gave $850 \pm$ $100 \mathrm{yr}$. The reason for the difference between the $\mathrm{C}^{14}$ ages of St-402 and St-403 is evidently that the burned material consisted in part of a dry fir which had grown $3000 \mathrm{yr}$ before its use. Such dry firs have been found to be very old (Östlund, 1959, p. 37-38; Lundqvist, 1959a), and it is a known fact that even nowadays the Lapps prefer dry fir for camp firing, owing to its very superior qualities for this purpose. 


\section{Hornavan series}

Charcoal from sites at Döudden, at Lake Hornavan, Arjeplog parish, Lappland $\left(66^{\circ} 04^{\prime} \mathrm{N}\right.$ Lat, $18^{\circ} 09^{\prime} \mathrm{E}$ Long), Sweden. The place is a small peninsula formed by drifting sand, bound by vegetation, containing several culture levels. The finds in the lower levels comprise stone artifacts only, but the upper levels contain some ceramics in addition. Coll. 1958 by Birgitta Hallgren and Göte Östlund; subm. by H. Hvarfner, Royal Office of Antiquities, Stockholm.

St-454. Döudden 2

$1920 \pm 80$

Thin, extensive layer of charcoal, covered by sand up to base of presentday vegetation, but situated above the uppermost reliable cultural layer.

St-455. Döudden 5

$1710 \pm 70$

Stratigraphically the same layer as St-454 but $5 \mathrm{~m}$ from that point.

St-457. Döudden 13

$1810 \pm 75$

Stratigraphically the same layer at a third point.

St-453. Döudden 1

Average: $6160 \pm 100$

Charcoal among the stones of a hearth at the lower surface of the lowermost cultural layer. Three preparations were made:

St-453A. Gross sample

$6260 \pm 225$

St-453F. Sifted sample, fine fraction

$6140 \pm 140$

St-453C. Sifted sample, coarse fraction

$6125 \pm 140$

St-456. Döudden 11

$6170 \pm 100$

Charcoal among the stones of another hearth at the same stratigraphic position as St-453. At least one stone scraper was found definitely related to the hearth.

Comment (H.H. and G.ö.) : the great age of the lowest samples is confusing, especially since the investigation St-453A,F, and C makes very unlikely any error similar to that mentioned in St-403 above. The work is being continued, and the intermediate layers will also be investigated.

\section{Stensele series}

Charcoal from hearths at site no. 690 at the bay Sörviken, Lake Storuman, Stensele parish, Lappland ( $65^{\circ} 08^{\prime} \mathrm{N}$ Lat, $17^{\circ} 03^{\prime} \mathrm{E}$ Long), Sweden. In this series is also included one sample from site no. 694 at the bay Stenselet, $5 \mathrm{~km}$ SSE of the above locality. The archaeologic findings are artifacts originating from several cultures ranging from the arctic stone age to the 18th century. Coll. 1954 and 1955 and subm. by H. Hvarfner, Royal Office of Antiquities, Stockholm.

St-407. Sörviken, hearth 2

$1150 \pm 80$

Connected finds are a stone arrow point, a stone scraper, and ceramics.

St-408. Sörviken, hearth 3

$1775 \pm 100$

Connected find is a silver loaf of very late design, (medieval or later).

St-409. Sörviken, hearth 4

$1100 \pm 85$

Connected finds are a whetstone, and a quartz arrow point. 
St-410. Sörviken, hearth 5

Connected finds are iron artifacts and asbestos-tempered ceramics.

St-411. Sörviken, hearth 6

$945 \pm 100$

No finds.

St-412. Sörviken, hearth 8

$310 \pm 120$

Connected finds are quartz scrapers.

St-413. Sörviken, section $\mathrm{K5}$

$1460 \pm 100$

Connected finds are fragments of bronze kettles, dated as about 1lth century A.D.. and ceramics.

St-418. Stenselet, hearth $5 B$

$1010 \pm 100$

Connected finds are fragments of bronze kettles, possibly dating from about the 1lth century A.D., and ceramics.

Comment (H.H. and G.ö.) : with the exception of St-408 and St-413, the age figures obtained are reasonable. Those two dates might be too old owing to the same cause as described in the comment in St-403, above.

St-435. Vejenäs

$1240 \pm 70$

Charcoal from the bottom of a pit trap, also used for cooking, found in a gravel ridge at Vejenäs, Arjeplog parish, Lappland (66 $16^{\circ} 15^{\prime} \mathrm{N}$ Lat, $16^{\circ} 48^{\prime}$ E Long), Sweden. Subm. by E. Manker, Nordiska Museet, Stockholm.

St-436. Alfta

$300 \pm 60$

Stem of an ackja (hollowed-out trunk sledge, snow boat) found 1952 in near-shore deposits of Lake Börnasen, Alfta parish, Helsingland $\left(60^{\circ} 17^{\prime} \mathrm{N}\right.$ Lat, $15^{\circ} 49^{\prime}$ E Long), Sweden. Subm. by E. Manker, Nordiska Museet, Stockholm.

St-437. Adak

$980 \pm 70$

Sled runner, found in the soil by the stream Skeppträskån, Adak, Malå parish, Lappland ( $65^{\circ} 20^{\prime} \mathrm{N}$ Lat, $17^{\circ} 33^{\prime} \mathrm{E}$ Long), Sweden. Subm. by E. Manker, Nordiska Museet, Stockholm.

\section{St-452. Järvträsk}

$1390 \pm 75$

Wooden spade found 1950 in soil at Järvträsk, Arvidsjaur parish, Lappland ( $65^{\circ} 13^{\prime} \mathrm{N}$ Lat, $16^{\circ} 39^{\prime} \mathrm{E}$ Long), Sweden. Subm. by E. Manker, Nordiska Museet, Stockholm.

\section{B. Southern Sweden}

Fiskeby, Horn, Bankälla, and Rogsta Hage series

Resin caulkings from grave fields, measured as part of the work on the chronology of late Bronze Age-Early Iron Age in Sweden. An earlier part of the Fiskeby series has been measured previously (Östlund 1959, p. 41). The present samples were taken from Fiskeby and three other grave fields in southern central Sweden, containing archaeologically comparable material. Coll. 1951-1952 and subm. by P. Lundström, Museum of National Antiquities, Stockholm. Descriptions have been made by Sahlström and Gejvall (1948, 1954) and by the submitter (Lundström, 1952a, b). 
Fiskeby

Location: Fiskeby, Ö. Eneby parish, Östergötland $\left(58^{\circ} 36^{\prime} \mathrm{N}\right.$ Lat, $16^{\circ}$

06 ' E Long), Sweden.

\begin{tabular}{|c|c|c|c|c|c|}
\hline St-405. & Fiskeby & 6. & Grave & No. 7 & $2140 \pm 140$ \\
\hline St-482. & Fiskeby & 13. & Grave & No. 290 & $2120 \pm 110$ \\
\hline St-481. & Fiskeby & 14. & Grave & No. 316 & $2100 \pm 80$ \\
\hline St-483. & Fiskeby & 15. & Grave & No. 198 & $2050 \pm 80$ \\
\hline St-484. & Fiskeby & 16. & Grave & No. 414 & $2335 \pm 85$ \\
\hline St-505. & Fiskeby & 17. & Grave & No. 614 & $1970 \pm 80$ \\
\hline St-506. & Fiskeby & 18. & Grave & No. 133 & $2110 \pm 80$ \\
\hline St-507. & Fiskeby & 19. & Grave & No. 283 & $1930 \pm 80$ \\
\hline St-508. & Fiskeby & 20. & Grave & No. 644 & $1990 \pm 75$ \\
\hline St-509. & Fiskeby & 21. & Grave & No. 542 & $\mathbf{2 0 7 0} \pm \mathbf{7 0}$ \\
\hline St-510. & Fiskeby & 22. & Grave & No. 681 & $1940 \pm 60$ \\
\hline
\end{tabular}

Horn

Location: Kyrkbacken, Horn parish, Västergötland $\left(58^{\circ} 31^{\prime} \mathrm{N}\right.$ Lat, $13^{\circ}$ 54' E Long), Sweden.

St-444. Horn 9. Grave No. 23273:109

$2100 \pm 70$

St-445. Horn 10. Grave No. 23273:119

St-446. Horn 11. Grave No. 23435:211

$\mathbf{2 2 4 0} \pm 90$

St-480. Bankälla

$2020 \pm 80$

Location: Bankälla, Välla, parish, Västergötland $\left(58^{\circ} 32^{\prime} \mathrm{N}\right.$ Lat, $13^{\circ} 56^{\prime}$ E Long), Sweden.

St-443. Rogsta Hage

$2470 \pm 100$

Location: Rogsta Hage, Tystherga parish, Södermanland $\left(58^{\circ} 51^{\prime} \mathrm{N}\right.$ Lat, $17^{\circ} 13^{\prime}$ E Long), Sweden.

\section{St-475. Säter, Östergötland $\quad 1805 \pm 70$}

Charcoal from a hearth in the upper part of the culture layer of the habitation site Säter III, Kvarsebo parish, Östergötland $\left(58^{\circ} 13^{\prime} \mathrm{N}\right.$ Lat, $16^{\circ}$ $35^{\prime}$ E Long), Sweden. This site is a main station of the Middle Neolithic Pitted Ware Culture. Coll. 1959 and subm. by Mats P. Malmer, Museum of National Antiquities, Stockholm. Comment (M.P.M.) : date shows that the hearth must be much later than the Stone Age settlement.

\section{St-486. Simunde, Gotland}

$910 \pm 70$

Sample of charcoal, collected in a refuse pit on a Stone Age dwelling place at Simunde, Hörsne (formerly Bara) parish, Gotland, Sweden $\left(56^{\circ} 36^{\prime}\right.$ N Lat, $18^{\circ} 38^{\prime}$ E Long), excavated 1957-1958. Subm. by B. Schönbäck, Museum of National Antiquities, Stockholm. Comment (B.S.) : the sample, presumed to belong to the Stone Age settlement, would have been of great importance for dating the later phase of the Gotlandic preceramic Stone Age culture. The difference of about $3500 \mathrm{yr}$ between the archaelogic dating and the $\mathrm{C}^{14}$ age, however, indicates that remains from a late Iron Age fireplace have been buried in the same Stone Age pit. 


\section{Broby series, Uppland}

The following samples were collected during the excavations 1955-1957 on a large prehistoric site at Broby, Börje parish, Uppland $\left(59^{\circ} 55^{\prime} \mathrm{N}\right.$ Lat, $17^{\circ} 32^{\prime}$ E Long), Sweden. The monuments excavated include house- and hut foundations, workshop, graves, etc., all belonging to a late Bronze Age culture. The chronological limits of this east-Scandinavian phase of the Bronze Age, especially its end, are very difficult to establish; the supposition that it in fact extends up to the fully developed Iron Age (3rd period of the Iron Age) is strengthened by some of the samples below. Subm. by B. Schönbäck, Museum of National Antiquities, Stockholm, who has published preliminary excavation reports (Schönbäck, 1952, 1959).

St-487. Broby 1, No. 34

$1950 \pm 200$

Charcoal from a refuse layer, outside grave no. 34 , which was built as a "house of the dead".

St-488. Broby 2, No. 34

$2930 \pm 100$

Lump of resin, collected in the same layer as the sample above, but about $10 \mathrm{~cm}$ lower.

St-489. Broby 3, No. 38

$2695 \pm 100$

Lump of resin from fill of burial mound (placed on top of a former hut?).

St-490. Broby 4, No. 53B

$2730 \pm 90$

Charcoal from a bronze-founder's furnace pit, overlain by a Late Bronze Age burial.

St-491. Broby 5, No. 53C

$\mathbf{2 4 7 0} \pm \mathbf{9 0}$

Sample like no. 4 from a similar pit, stratified in the same way.

St-493. Vildmossen

$1090 \pm 100$

Peat containing plaited plant fibers, found 1955 in the bog Vildmossen, Nässjö, Småland ( $57^{\circ} 41^{\prime} \mathrm{N}$ Lat, $14^{\circ} 39^{\prime} \mathrm{E}$ Long), Sweden, at a depth of 1.8 to $2 \mathrm{~m}$ below the surface. The find was located about $150 \mathrm{~m}$ from the shoreline of a former lake, now occupied by the bog. Subm. by A. Oldeberg, Museum of National Antiquities, Stockholm.

\section{St-406. Linköping}

$300 \pm 60$

Wood from a door frame in basement of a medieval house at the ancient Bishop Court, Linköping, Östergötland $\left(58^{\circ} 25^{\prime} \mathrm{N}\right.$ Lat, $15^{\circ} 37^{\prime} \mathrm{E}$ Long $)$, Sweden. The question was to decide whether the material belonged to the Medieval Age or if the tree had been cut for a repair made in A.D. 1737. Coll. and subm. by E. Ridderstad, Linköping. Comment (G.ö.) : no absolutely certain conclusion can be drawn from the obtained $\mathrm{C}^{14}$ age, but the younger alternative is more probable.

\section{Khirokitia series}

\section{Archaeologic Samples-Other Countries}

Samples of charcoal in the pre-pottery levels from the Neolithic I settlement of Khirokitia, Cyprus ( $34^{\circ} 47.5^{\prime} \mathrm{N}$ Lat, $33^{\circ} 20.5^{\prime} \mathrm{E}$ Long). The layer was grayish soil containing flint and obsidian implements together with the charcoal, probably the result of burnt superstructures of mud and brushwood. 
Archaeologic dating of the settlement was 3700-3400 B.c. (Dikaios, 1953, p. 314-315); it is considered to be the oldest so far discovered in Cyprus. Coll. and subm. by P. Dikaios, Cyprus Museum, Nicosia, Cyprus.

\section{St-414. Khirokitia 1}

Sample from the lowest layer in the north sector of the corridor surrounding Tholos I A (Dikaios, 1953, p. 1, and pl. VI).

St-415. Khirokitia 2

$7710 \pm 160$

Check sample, same details as for St-414.

\section{Average of St-414 and St-415}

St-416. Khirokitia 3

$7635 \pm 100$

Sample from the layers under the northwest stone of the fou Tholos XVII (Dikaios, 1953, fig. 50).

Comment (P.D.) : There is an unexpected gap of almost two millenia between the Khirokitia pre-pottery culture and the Sotira combed ware culture (Dikaios, in press). The present dates are very important for Cypriot prehistory.

St-419. Kalavassos B

$\mathbf{5 1 4 0} \pm \mathbf{1 1 0}$

Charcoal belonging to the Kalavassos B Culture at Kalavassos, Cyprus ( $34^{\circ} 44.5^{\prime} \mathrm{N}$ Lat, $33^{\circ} 19^{\prime} \mathrm{E}$ Long). The samples were collected from a layer under floor VI (the lowest) overlying bedrock in the half-sunk dwelling VIII (Dikaios, 1953, p. 314). The cultural stage to some extent corresponds to the Erimi culture. The main feature from the ceramic point of view is the presence of red on white pottery, but some combed pottery did occur, thus linking the Kalavassos B culture with the earlier Sotira culture belonging to the Neolithic II period. Samples from the Sotira culture were dated earlier at about 5150 and about 5460 в.P. (Östlund, 1959, St-350 and St-337). Coll. 1947 and subm. by P. Dikaios, Cyprus Museum, Nicosia, Cyprus. Comment (P.D.) : age obtained checks well with the Sotira dates.

\section{GEOPHYSICAL AND OTHER SAMPLES}

\section{Tree ring series}

Samples of tree rings cut from an oak felled in 1953 at Djurgården, Stockholm (59 $20^{\prime} \mathrm{N}$ Lat, $18^{\circ} 08^{\prime} \mathrm{E}$ Long), Sweden. The rings around A.D. 1850 have been used as our standard. Each sample includes the given number of rings before and after the year stated. The values are $\mathrm{C}^{13}$-corrected in the usual way, and also corrected for radioactive decay. Coll. by G. Östlund.

\begin{tabular}{|c|c|c|c|c|}
\hline & & & $\partial \mathrm{C}^{13}$ & $\triangle \mathrm{C}^{14}$ \\
\hline St-358. & Oak & $1710 \pm 5$ & $(+9 \pm 2 \% o)$ & $+22 \pm 5 \%$ \\
\hline St-359. & Oak & $1810 \pm 5$ & $(+2 \pm 2 \% 0)$ & $+1 \pm 5 \%$ \\
\hline Standard & Oak & $1850 \pm 5$ & $\left(\begin{array}{ll}0 & \% o\end{array}\right)$ & $0 \pm 4 \%$ \\
\hline St-360. & Oak & $1910 \pm 3$ & $(+5 \pm 2 \% 0)$ & $-18 \pm 5 \%$ \\
\hline St-386. & Oak & $1950 \pm 1$ & $\left(0 \pm 2 \%_{0}\right)$ & $-23 \pm 5 \%$ \\
\hline
\end{tabular}

Comment (G.ö.) : the trend among the first three samples is similar to the 
result obtained by de Vries (1958). The Suess effect appears to be $23 \pm 7 \%$ o in Stockholm. In order to convert to the accepted value of 0.95 times the NBS $\mathrm{C}^{14}$ scale, add $+7 \%$ to the given $\mathrm{C}^{14}$ figures. In order to convert to the PDB- $\mathrm{C}^{13}$ scale, subtract 25 from the $\mathrm{C}^{13}$ figures.

\section{Garpenberg series}

Soil humus samples from a profile in a spruce forest, 95 years old, at Garpenberg, Dalarna ( $60^{\circ} 33^{\prime} \mathrm{N}$ Lat, $16^{\circ} 13^{\prime} \mathrm{E}$ Long), Sweden. Altitude 200 m. Coll. 1958 and subm. by C.-O. Tamm, Forest Research Institute, Stockholm 51. The series is described in more detail and discussed by Tamm and Östlund (1960), and was made as an attack on the problem of the residence time of organic matter in the soil. The result below is given as per mil deviation from our Stockholm oak standard and is $\mathrm{C}^{13}$-corrected as usual. In order to obtain the values in the NBS-standard scale, add $+7 \%$.

$$
\begin{array}{ll}
\text { St-472. Mor } & -7 \pm 5 \% \text { C } \mathrm{C}^{14}
\end{array}
$$

Raw humus, $\mathrm{A}_{0}$-horizon. Ash content $54.5 \%$ of dry weight.

St-473. Mineral soil

$$
-20 \pm 5 \% \mathrm{C}^{14}
$$

Dark-colored mineral soil, $\mathrm{A}_{1}$-horizon. Ash content $84.1 \%$ of dry weight.

St-474. Accumulation horizon $\quad \mathbf{4 4} \pm \mathbf{5 \%} \% \mathrm{C}^{\mathbf{1 4}}$

Accumulation, B-horizon. Dark brown to rust in color. Ash content $94.8 \%$ of dry weight.

Comment (C.O.T. and G.Ö.) : the last result corresponds to a formal $\mathrm{C}^{14}$ age of $370 \mathrm{yr}$.

\section{Adriatic Sea series}

Black sapropelitic mud from a core, $2.5 \mathrm{~m}$ long, taken in the Adriatic Sea (44 $58^{\prime} \mathrm{N}$ Lat, $12^{\circ} 54^{\prime} \mathrm{E}$ Long), water depth $33 \mathrm{~m}$. The top of the sediments may be missing owing to erosion. Samples were taken in order to obtain an indication of the rate of sedimentation, which in turn may be used to estimate the fallout of black, magnetic, so-called "cosmic spherules" included in the sediments. Subm. by K. Fredriksson, Geological Survey of Sweden.

St-426. Adriatic Sea A

$9240 \pm 180$

102 to $103 \mathrm{~cm}$ below the present top surface.

St-427. Adriatic Sea B

$8960 \pm 170$

106 to $109 \mathrm{~cm}$ below the present top surface.

REFERENCES

Broecker, W. S., and Olson, E. A., 1959, Lamont radiocarbon measurements VI: Am. Jour. SCI. Radioc. SuPP., v. l, p. 111-132

Dikaios, P., 1953, Khirokitia: Oxford, Oxford Univ. Press.

in press, Swedish Cyprus Expedition IV, no. 1.

Lundqvist, $G$ 1959a, C14-dated pine stumps from the high mountains of western Sweden [ in Swedish, summ. in English]: Sveriges geol. undersökning, ser. C, no. 565.

[ in Swedish, summ. in Eng till geologiska kartbladet Eskilstuna [summ. in English]: Sveriges geol. undersökning, ser. Aa, no. 200.

Lun 1952b, Gravfältsundersökning vid Fiskeby 1952: Fornvännen, v. 47, p. 281.

Östlund, H. G., 1957a, Stockholm natural radiocarbon measurements I: Science, v. 126,

p. $493-497$. $1957 \mathrm{~b}$, Carbon dioxide proportional counting for natural radiocarbon measurements: Arkiv f. Kemi, v. 12, no. 6, p. 69-78. 
1959, Stockholm natural radiocarbon measurements II: AM. Jour. ScI. Radioc. SuPP., v. 1, p. 35-44.

Sahlström, K. E., and Gejvall, N.-G., 1948, Gravfältet på Kyrkbacken i Horns socken, Västergötland: Kungl. Vitterhetsakad. Handl. no. $60: 2$.

1954, Bankälla och stora Ro, Två västgötska brand-grops gravfält: Kungl. Vitterhetsakad. Handl. no. 89.

Schönbäck, B., 1952, Bronsåldershus i Uppland: Tor (Univ. Uppsala. Arch. Inst.), v. 1949-1951, p. 23-45.

Tamm 1959, Bronsåldersbygd i Mälarområdet: Tor, v. 1959, p. 52-107.

Tamm, C. O., and Östlund, H. G., 1960, Radiocarbon dating of soil humus: Nature, v. 185 , p. $706-707$.

Vries, Hessel de, 1958, Variation in the concentration of radiocarbon with time and location on Earth: Koninkl. Nederlandse Akad. Wetensch. Proc., ser. B, v. 6il, no. 2, p. $1-9$. 